\title{
Response of Onion to Inoculation with Vesicular Arbuscular Mycorrhiza and Phosphorus Solubilizing Bacteria under Varying Levels of Phosphorus
}

\author{
Z.M. Dar ${ }^{1 *}$, A. Masood ${ }^{2}$, M. Asif ${ }^{1}$ and M.A. Malik ${ }^{1}$ \\ ${ }^{1}$ Division of Basic Sciences and Humanities, Faculty of Agriculture, Wadura Sopore, \\ SKUAST-K, India \\ ${ }^{2}$ Division of Agronomy Faculty of Agriculture, Wadura Sopore, SKUAST-K, India \\ *Corresponding author
}

\section{A B S T R A C T}

\begin{tabular}{|l|}
\hline Ke y w or d s \\
Vesicular \\
arbuscular \\
mycorrhiza, \\
$\begin{array}{l}\text { Phosphate } \\
\text { solubilizing } \\
\text { bacteria, } \\
\text { Phosphorus }\end{array}$ \\
\hline Article Info \\
\hline $\begin{array}{l}\text { Accepted: } \\
\text { 17 January 2018 } \\
\text { Available Online: } \\
10 \text { February 2018 }\end{array}$ \\
\hline
\end{tabular}

Keywords

Vesicular

arbuscular

solubilizing

bacteria,

Phosphorus

Accepted:

Available Online:

10 February 2018

\begin{abstract}
A field experiment was carried out to find out the response of onion to individual and combined inoculation of vesicular arbuscular mycorrhiza (VAM) and phosphate solubilizing bacteria (PSB) under different levels of phosphorus (P) at FOA Wadura Sopore, Kashmir. The results revealed that, combined inoculation of onion with VAM and PSB significantly increased all the examined parameters during the study as compared to control as well as to their individual inoculations even when the $\mathrm{P}$ inoculation was reduced to 75 and $50 \%$ of the recommended dose. However, the best results were obtained at $75 \%$ of $\mathrm{P}$ with combined inoculation of VAM and PSB as is evident from 29.2 and $8.5 \%$ increase in bulb dry weight and bulb yield respectively. Similarly at the same treatment the quality parameters like total soluble salts (TSS), nitrogen $(\mathrm{N})$, phosphorus (P) and potassium (K) content of the bulbs was increased by 26.6, 42.8, 68.4 and $21.7 \%$ as compared to control.
\end{abstract}

\section{Introduction}

Onion is grown as spice and vegetable crop and used for culinary purpose. Raw onion has an antiseptic value, promotes bile production and reduces blood sugar. It is rich source of phosphorus, calcium, vitamin $\mathrm{C}$, protein and carbohydrates. Onion is known to check the deposition of cholesterol in blood vessels, thus protect against heart diseases resulting from blockage of arteries (Barakade et al., 2011).
Phosphorus $(\mathrm{P})$ is an essential macroelement for plants, yet the total concentration of $\mathrm{P}$ in soils ranges from $0.02-0.5 \%$. Thus, to increase the availability of phosphorus for plants, large amount of fertilizers are used on a regular basis, yet after inoculation, a large proportion of phosphorus is quickly transferred to an insoluble form (Omar, 1997). But on the other hand the indiscriminate use of chemicals resulted in degradation of soil health, erosion, and loss of 
organic matter, nitrate pollution and also health hazard for human beings (Ghanti and Sharangi, 2009). Heavy inoculation of inorganic fertilizers degrade the soil health by adversely affecting the microbial biodiversity, physical and chemical environment of soil, water bodies and capital inputs like soil, water and thus overall ecology. In addition, the increasing cost of inorganic fertilizers is making onion production an uneconomical occupation for small and marginal farmers. So for sustainable production of crops alternative technologies that could replace the inoculation of inorganic fertilizers to some extent seem to be the need of hour. In this regard the inoculation of microorganisms like VAM and PSB seems to be an attractive solution that has been actively studied during the last decade so that dependence on inorganic fertilizers can be reduced as they have got the ability to supplement phosphorus, nitrogen, potassium, zinc etc to the plant.

VAM are widespread in nature and are fundamental component of the agroecosystem (Bethlenfalvay et al., 1997). One of the most dramatic effects of infection by mycorrhizal fungi on the host plant is the increase in P uptake (Roger, 1991), mainly due to the capacity of the mycorrhizal fungi to absorb phosphate from soil and transfer it to the host roots (Asimi et al., 1980). PSB are beneficial bacteria capable of solubilizing inorganic phosphorus from insoluble compounds. $\mathrm{P}$ solubilization ability of rhizosphere microorganisms is considered to be one of the most important traits associated with plant phosphate nutrition. It is generally accepted that the mechanism of mineral phosphate solubilization by PSB strains is associated with the release of low molecular weight organic acids, through which their hydroxyl and carboxyl groups chelate the cations bound to phosphate, thereby converting it into soluble forms (Rashid et al., 2004).

\section{Materials and Methods}

A field experiment was carried out at Faculty of Agriculture, Wadura Sopore (SKUAST-K). The soil of the experimental field is sandy loam with an EC of $0.33 \mu \mathrm{S} / \mathrm{cm}$ and $\mathrm{pH}$ 7.3. The experimental area was thoroughly prepared by ploughing the soil three times. Well decomposed farm yard manure (FYM) was applied at the rate of $25 \mathrm{t} /$ ha after ploughing the land. Seven treatments shown in the table 1 were employed which were laid out in a randomized block design and replicated thrice. A recommended dose of $\mathrm{N}$ was applied to the plots in two doses, one at the time of transplanting and second in the month of March, whereas the entire $\mathrm{P}$ as per the designed treatments and $\mathrm{K}$ was applied in a single dose at the time of transplanting. VAM was applied in the root zone at the time of transplanting, whereas seedlings were dipped in a solution of PSB for 45 minutes before transplanting. All the required cultural practices such as irrigation, weeding, pest and disease control etc. were kept constant and given uniformly in all the experimental plots. Ten plants were randomly selected from each plot in such a way that the marginal effect was avoided and data were recorded on

1. Plant height: Plant height was measured with the help of a scale.

2. Bulb fresh weight: bulb fresh weight was measured immediately after harvesting and removing the soil particles adhered to the bulb.

3. Bulb dry weight: Bulb dry weight was measured after keeping the bulbs in oven at $70{ }^{0} \mathrm{C}$ till the weight became constant.

4. Bulb diameter: Bulb diameter was measured with the help of caliper.

5. Total soluble solids (TSS): TSS of the bulbs was measured by using the hand refractometer.

6. Estimation of Nitrogen $(\mathrm{N})$ : $\mathrm{N}$ content from the bulbs was determined by using 
the method as proposed by Peoples et al. (1989)

7. Determination of Phosphorus (P): $\mathrm{P}$ content was estimated from the bulbs as per the method proposed by Koenig and Johnson (1942).

8. Determination of potassium $(\mathrm{K})$ : $\mathrm{K}$ was estimated by flame photometeric method as proposed by Reed and Scott (1962).

\section{Statistical analysis}

The data reported in this study were the mean values based on the three replicates. Differences among treatments were tested by ANOVA and the mean values among the treatments were compared using Duncan's multiple range test at $\mathrm{p}=0.05$.

\section{Results and Discussion}

\section{Plant height}

The data pertaining to plant height shows that plant height at the harvesting varied at the different treatments. Plant height showed slight increase at $\mathrm{T} 1$ and $\mathrm{T} 4$ whereas; it recorded a decrease at $\mathrm{T} 2$ and $\mathrm{T} 3$ treatments. The results were highly significant at $\mathrm{T} 5$ with an increase of $11.2 \%$ which is at par with T6 where an increase of $8.3 \%$ was reported as compared to control (Table 2). The results are in agreement with Naik (2014). The increased growth of onion in terms of plant height by combined inoculation of VAM and PSB at reduced level of $\mathrm{P}$ might be due to higher solubilization of $\mathrm{P}$ brought about by PSB followed by its increased uptake along with $\mathrm{N}$ and $\mathrm{K}$ as is evident from table 3 of this study. Inoculation with VAM increases the absorbing capacity of the roots favoring more water uptake by the plants resulting in cell expansion responsible for the increased plant height (Huixing Song, 2005). Since nitrogen is a constituent of chlorophyll, the increase uptake of which might have resulted in increased synthesis of photosynthates leading to better plant growth. The second major nutrient phosphorus is an essential constituent of cellular protein and nucleic acid which might have encouraged the cell division and meristematic activity of plants resulting in increased plant height (Monika et al., 2006).

\section{Bulb fresh and dry weight}

The variations in bulb fresh and dry weight are evident from table 2 which indicates an increase in both the parameters at all the treatments. However the maximum increase with respect to both the parameters was observed at T5 and T6. Bulb fresh weight recorded an increase of 20.4 and $19.0 \%$ respectively at $\mathrm{T} 5$ and $\mathrm{T} 6$ whereas at the same treatments the bulb dry weight was increased by 29.2 and $27.1 \%$ as compared to control. The results are in accordance with (Naik, 2014). The increase in bulb dry weight can be contributed to increased plant photosynthetic rate achieved by VAM inoculation through increased leaf stomatal conductance as compared to non inoculated plants resulting in more $\mathrm{CO}_{2}$ uptake (Huixing Song, 2005). K which is an activator of enzymes involved in protein and carbohydrate metabolism plays an important role in the translocation of photosynthates from leaves of bulb which would have been utilized in building up of new cells and tissues leading to increased bulb fresh and dry weight as has been in reported in case of potato by Hans-Eckhard et al., (1973).

\section{Bulb diameter and bulb yield}

All the treatments differed significantly with each other with respect to bulb diameter and yield. Information made available in table 2 revealed that T5 and T6 once again showed the supremacy among all the treatments in increasing the bulb diameter and yield. A respective increase of 31.6 and $27.8 \%$ was 
recorded in the bulb diameter at $\mathrm{T} 5$ and $\mathrm{T} 6$ whereas bulb yield recorded an increase of 8.5 and $2.6 \%$ respectively at $\mathrm{T} 5$ and $\mathrm{T} 6$ as compared to control. The results are in conformity with the findings of Tyagi and Yadav (2007). The increase in bulb diameter and bulb yield may be due to the role of biofertilizers inoculation on increasing the availability and uptake of nitrogen, phosphorus, potassium, zinc etc by the onion plant. In addition, greater root proliferation and absorbing capacity for water, more photosynthetic area and enhanced food accumulation by the bulbs contribute to their increased yield (Balemi et al., 2007).

Table.1 Treatment details

\begin{tabular}{|c|c|c|c|c|c|c|}
\hline T0 & T1 & T2 & T3 & T4 & T5 & T6 \\
\hline Control & $\begin{array}{l}75 \% \text { of } \mathrm{P}+ \\
\text { VAM }\end{array}$ & $\begin{array}{l}50 \% \text { of } \mathrm{P}+ \\
\text { VAM }\end{array}$ & $\begin{array}{l}75 \% \text { of } \mathrm{P}+ \\
\mathrm{PSB}\end{array}$ & $\begin{array}{l}50 \% \text { of } \mathrm{P}+ \\
\mathrm{PSB}\end{array}$ & $\begin{array}{l}75 \% \text { of } \mathrm{P}+ \\
\text { VAM+PSB }\end{array}$ & $\begin{array}{l}50 \% \text { of } \mathrm{P}+ \\
\mathrm{VAM}+\mathrm{PSB}\end{array}$ \\
\hline
\end{tabular}

Table.2 Effect of different levels of phosphorus, PSB and VAM on growth and yield of onion

\begin{tabular}{|c|c|c|c|c|c|}
\hline Treatments & $\begin{array}{l}\text { Plant height } \\
\text { (cm) }\end{array}$ & $\begin{array}{l}\text { Bulb fresh } \\
\text { weight (g) }\end{array}$ & $\begin{array}{l}\text { Bulb dry } \\
\text { weight (g) }\end{array}$ & $\begin{array}{l}\text { Bulb diameter } \\
\text { (cm) }\end{array}$ & $\begin{array}{l}\text { Bulb yield } \\
\text { (T/ha) }\end{array}$ \\
\hline T0 & 48.2 & 75.0 & 62.1 & 15.3 & 14.9 \\
\hline T1 & 50.1 & 79.9 & 69.2 & 18.4 & 13.9 \\
\hline T2 & 47.3 & 77.5 & 70.4 & 17.1 & 12.1 \\
\hline T3 & 47.5 & 84.5 & 76.3 & 19.2 & 13.2 \\
\hline T4 & 49.4 & 90.8 & 84.8 & 18.6 & 11.4 \\
\hline T5 & 54.3 & 94.3 & 87.8 & 22.4 & 16.3 \\
\hline T6 & 52.6 & 92.7 & 85.2 & 21.2 & 15.3 \\
\hline $\begin{array}{l}\text { CD } \\
P=0.05\end{array}$ & 0.13 & 0.12 & 0.12 & 0.06 & 0.97 \\
\hline
\end{tabular}

Table.3 Effect of different levels of phosphorus,s PSB and VAM on quality parameters of onion

\begin{tabular}{|l|l|l|l|l|}
\hline Treatment & TSS $(\boldsymbol{\%})$ & $\mathbf{N}$ & $\mathbf{P}$ & $\mathbf{k}$ \\
\hline T0 & 11.3 & 2.0 & 0.06 & 1.73 \\
\hline T1 & 10.9 & 2.4 & 0.12 & 1.79 \\
\hline T2 & 9.8 & 2.9 & 0.08 & 1.82 \\
\hline T3 & 10.5 & 2.2 & 0.16 & 1.89 \\
\hline T4 & 9.5 & 2.5 & 0.14 & 1.90 \\
\hline T5 & 15.4 & 3.5 & 0.19 & 2.21 \\
\hline T6 & 13.4 & 3.0 & 0.17 & 1.95 \\
\hline $\begin{array}{l}\text { CD } \\
\text { P }=\mathbf{0 . 0 5}\end{array}$ & $\mathbf{0 . 9}$ & $\mathbf{3 . 2}$ & $\mathbf{2 . 7}$ & $\mathbf{1 . 8}$ \\
\hline
\end{tabular}




\section{Total soluble solids}

Total soluble solids were found to decrease when VAM and PSB were separately used with the different levels of P. However table 3 shows that there was a significant increase in TSS when a combined inoculation was made with VAM and PSB at $75 \%$ of the P. TSS at T5 was found to be increased by $26.6 \%$ whereas at T6 it was increased by $15.6 \%$ as compared to control. Same results in this regard have been found by Talwar et al. (2017) who found that inoculation with biofertilizers resulted in significantly higher TSS. The increase in TSS can be contributed to increased chlorophyll content which increases the photosynthetic rate of the plant (Mathur and Vyas, 2000). In addition more availability and uptake of $\mathrm{K}$ (Table 3) which is having an important role in the translocation of photosynthates also might have contributed to increased TSS of onion by the combined inoculation with VAM and PSB.

\section{Mineral uptake}

Combined inoculation with VAM and PSB had a significant effect on the mineral uptake of the onion plant. Table 3 indicates that $\mathrm{N}, \mathrm{P}$ and $\mathrm{K}$ content of the onion bulbs was increased at all the treatments; however the maximum values were recorded at $\mathrm{T} 5$ followed by T6. As compared to control N, P and $\mathrm{K}$ content showed a respective increase of $42.8,64.4$ and $21.7 \%$ at T5 where VAM and PSB were used in combination with $75 \%$ of P. Similar results have also been found by Talwar et al., (2017) and Hashem (2015).

Microorganisms can increase the solubility of inorganic $\mathrm{P}$ by releasing protons, $\mathrm{H}^{+}$and organic acid anions such as citrate, malate and oxalate (Yousefi et al., 2011) whereas the VAM fungus absorbs the mineral elements like N, P, K, Fe, Zn etc much faster through physical exploration of the soil, modification of root environment, increased movement of various mineral elements into mycorrhizal fungus hyphae and their translocation to the associated plant (Turk, et al., 2006).

\section{References}

Asimi, S., Gianinazzi-Pearson, V., and Gianinazzi, S. 1980. Influence of increasing soil phosphorus levels on interactions between vesiculararbuscular mycorrhizae and Rhizobium in soybeans. Canadian Journal of Botany. 58(20): 2200-2205

Balemi, T., Pal, N., Saxena, A.K. 2007. Response of onion (Allium cepa L.) to combined inoculation of biological and chemical nitrogenous fertilizers. Acta Agriculturae Slovenica. 89(1): 107-114

Barakade, A. J., Lokhande T.N. and Todkari G.U. (2011). International Journal of Agricultural and Statistical Science. 3: 110-117.

Bethlenfalvay, G.J., R.B. Schreiner and Mihara, K.L. 1997. Mycorrhizal fungi effects on nutrient composition and yield of soybean seeds. J. Plant Nutr. 20: 581-591.

Ghanti, S. and Sharangi, A. B. 2009. Effect of bio-fertilizers on growth, yield and quality of onion cv. Sukhsagar. J. Crop Weed 5:120-123.

Hans-Eckhard, H., Konrad, M, and Helmut, Fors. 1973. The effect of potassium on translocation of photosynthates and yield pattern of potato plants. Journal of the Science of Food and Agriculture. 24(12): 1479-1487.

Hashem, M. M. 2015. Impact of Inoculation with arbuscular mycorrhizal, phosphate solubilizing bacteria and soil yeast on growth, yield and phosphorus content of onion plants. International J. of Soil Sci. 10(2): 93-99

Huixing, S (2005). Effects of VAM on host 
plant in the condition of drought stress and its mechanisms. Electronic $J$. of Biol: (3) 44-48

Koenig, R. and Johnson, C. 1942. Colorimetric determination of phosphorus in biological materials. Ind. Eng. Chem. Anal. 14(2): 155-156

Mathur, N and Vyas, A. 2000. Influence of arbuscular mycorrhizae on biomass production nutrient uptake and physiological changes in Ziziphus mauritiana Linn. under water stress. Journal of Arid. Environment. 45: 191195.

Monika, K., Fernando, A. L., Agustin, A. G. and Hans, S. 2006. Phosphorus deficiency decreases cell division and elongation in grass leaves. Plant Physiology. 141(2): 766-775.

Naik, M. R. (2014). Effect of inorganic fertilizers, PSB and VAM on growth and yield of onion. Mysore journal of Agricultural Sciences. 48(3): 460-463.

Omar, S.A. 1997. The role of rockphosphate-solubilizing fungi and vesicular-arbusular-mycorrhiza (VAM) in growth of wheat plants fertilized with rock phosphate. World Journal of Microbiology and Biotechnology. 14: 211-218

Peoples, M.B., Faizah, A.W., Rerkasem, B., and Herridge, D.F. 1989. Methods for evaluating nitrogen fixation by nodulated legumes in the field. ACIAR Monograph. 2(7): 76

Rashid, M., Khalil, S., Ayub, N., Alam, S. and Latif, F. 2004. Organic acids production and phosphate solubilization by phosphate solubilizing microorganisms (PSM) under in vitro conditions. Pakistan Journal of Biological Sciences. 7: 187-196.

Reed, M.G. and Scott, A.D. 1962. Chemical extraction of potassium from soils and micaceous minerals with solution containing sodium tetraphenylboron, II. Biotite. Soil Science Society of. American Proceedings. 26:41-45.

Roger, T. K. 1991. Nutrient supply, nutrient demand and plant response to mycorrhizal infection. New Phytologist. 117(3): 365-386

Talwar, D., Singh, K., Sardana, V. and Singh J. 2016. Growth, yield and quality of onion as influenced by integrated nutrient management. International journal of agriculture 8(51): 22952298.

Turk, M.A., Assaf, T.A., Hameed, K.M., AlTawaha, A.M. 2006. Significance of mycorrhizae. World Journal of Agricultural Sciences 2 (1): 16-20.

Tyagi, A. K. and Yadav, S. K. 2007. Effect of growth regulators on growth and yield of onion (Allium cepa L.) cv. Pusa Red. Plant Archives .7 (1): 371-372.

Yousefi, A.A., Khavazi, K., Moezi, A.A., Rejali, F. and Nadian, N.H. 2011. Phosphate solubilizing bacteria and arbuscular mycorrhizal fungi impacts on inorganic phosphorus fractions and wheat growth. World Applies Sciences Journal. 15 (9): 1310-1318.

\section{How to cite this article:}

Dar, Z.M., A. Masood, M. Asif and Malik, M.A. 2018. Response of Onion to Inoculation with Vesicular Arbuscular Mycorrhiza and Phosphorus Solubilizing Bacteria under Varying Levels of Phosphorus. Int.J.Curr.Microbiol.App.Sci. 7(02): 2018-2023. doi: https://doi.org/10.20546/ijcmas.2018.702.241 